\title{
Hubungan Kadar Neuron-Specific Enolase Serum dengan Mortalitas pada Sepsis Neonatorum
}

\author{
Ricky Hartanto, Nurhayati Masloman, Johnny Rompis, Rocky Wilar \\ Departemen Ilmu Kesehatan Anak Fakultas Kedokteran Universitas Sam Ratulangi/ RS Prof dr. R.D. Kandou, Manado
}

Latar belakang. Sepsis neonatorum menyebabkan respons inflamasi berlebih sehingga terjadi kerusakan sawar darah otak, disfungsi serebrovaskular dan oksigenasi, gangguan neurotransmiter, degenerasi sel neuron, edema serebral yang berakhir pada kematian sel. Penelitian sebelumnya mendapatkan peningkatan kadar NSE serum pada pasien anak dengan sepsis berat dan syok septik.

Tujuan. Mengetahui hubungan kadar NSE serum dengan mortalitas pada sepsis neonatorum.

Metode. Digunakan metode analitik observasional kohort prospektif dari bulan Agustus 2015 sampai November 2015. Sampel diambil secara konsekutif dan didapatkan 42 bayi dengan sepsis neonatorum. Analisis statistik diuji dengan regresi logistik dan korelasi Pearson. Orang tua atau wali diminta menandatangani informed consent. Penelitian ini dilaksanakan dibawah persetujuan komite etik. Hasil. Terdapat hubungan antara kadar NSE serum dengan mortalitas (koefisien korelasi $\mathrm{r}_{\mathrm{p}}=0,738$ dengan nilai $\mathrm{p}<0,001$ ). Cutt-off point kadar NSE serum yaitu 21,9 $\mu \mathrm{g} / \mathrm{L}$ dengan sensitivitas $91,3 \%$ dan spesifisitas $94,7 \%$ dalam menentukan mortalitas pada sepsis neonatorum.

Kesimpulan. Semakin tinggi kadar NSE serum maka semakin besar peluang bayi dengan sepsis akan meninggal. Sari Pediatri 2016; 17(6):450-4.

Kata kunci: neuron-specific enolase, mortalitas, sepsis neonatorum

\section{Relationship between Neuron-Specific Enolase (NSE) and Mortality in Neonatal Sepsis}

Ricky Hartanto, Nurhayati Masloman, Johnny Rompis, Rocky Wilar

Background. Neonatal sepsis causes excessive inflammatory responses, which in turn causes damage to the blood brain barrier, cerebrovascular dysfunction and oxygenation, neurotransmitter disorders, neuron degeneration, and cerebral edema, that ended in the cell death. Previous studies showed elevated levels of serum NSE in pediatric patients with severe sepsis and septic shock.

Objective. To determine the relationship of serum NSE levels with mortality in neonatal sepsis.

Method. We conducted an observational analytical study with prospective cohort approach from August 2015 until November 2015. Samples were taken consecutively. Forty-two infants with neonatal sepsis were enrolled into the study. The relationship between serum NSE levels with mortality was tested with logistic regression analysis and Pearson correlation test. Informed consent was obtained from parents or guardians. This study was approved by ethical comittee.

Results. There is a significant correlation between serum NSE levels with mortality in neonatal sepsis (correlation coefficient $\mathrm{r}_{\mathrm{pb}}=$ 0.738 with $\mathrm{p}<0.001$ ). Cut-off point of serum NSE levels to determine risk of mortality is $21.9 \mu \mathrm{g} / \mathrm{L}$ with a sensitivity of $91.3 \%$ and specificity of $94.7 \%$.

Conclusion. This study shows that the higher levels of serum NSE, the greater chances of newborns with sepsis will die. Sari Pediatri 2016; 17(6):450-4.

Key words: neuron-specific enolase, mortality, neonatal sepis Alamat korespondensi: Dr. Ricky Hartanto. Departemen Ilmu Kesehatan Anak Fakultas Kedokteran Universitas Sam Ratulangi/ RS Prof dr. R.D.
Kandou, Manado. Tel. +62 (431) 821652, Fax. +62 (431) 859091, E-mail: kiha_med@yahoo.com 


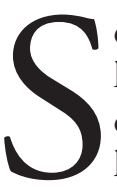

epsis neonatorum merupakan masalah kesehatan yang belum dapat ditanggulangi dalam pelayanan dan perawatan bayi baru lahir. Sepsis neonatorum adalah sindrom klinis penyakit sistemik yang ditandai adanya mikroorganisme dalam darah dan terjadi pada bulan pertama kehidupan. Sampai saat ini, sepsis neonatorum merupakan penyebab utama morbiditas dan mortalitas pada bayi baru lahir. Pada bulan pertama kehidupan, infeksi yang terjadi berhubungan dengan angka kematian yang tinggi, yaitu 13\%-15\%. ${ }^{1}$

Diagnosis sepsis sering sulit ditegakkan karena gejala klinis yang tidak spesifik pada neonatus. Pemeriksaan kultur darah merupakan baku emas penegakan diagnosis sepsis neonatorum, tetapi pemeriksaan tersebut hasilnya baru dapat diketahui setelah 48 sampai 72 jam. Selain itu, penyebab infeksi masih sulit dibedakan antara virus dan bakteri. Kesalahan klasifikasi infeksi virus akan menyebabkan pemakaian antibiotik yang tidak perlu dan biaya yang lebih besar. Keterlambatan diagnosis dan tata laksana sepsis neonatorum akan menyebabkan bayi mengalami sepsis berat. ${ }^{1,2}$

Sepsis melibatkan interaksi kompleks antara mikroorganisme patogen dan pejamu yang akan menimbulkan respons inflamasi dengan meningkatnya sekresi mediator inflamasi, seperti sitokin, protein fase akut, dan penimbunan leukosit pada jaringan yang terinfeksi. Sepsis dapat menyebabkan hipotensi dan obstruksi aliran darah akibat pembentukan mikrotrombus pada sistem kapiler. Hal ini akan menyebabkan disfungsi organ, kemudian disfungsi multiorgan dan berujung pada kematian..$^{3-5}$

Kegagalan multiorgan dapat mengenai susunan saraf pusat (SSP), walaupun dilindungi dengan sawar darah otak, masih rentan terhadap gangguan sistemik yang disebabkan oleh sepsis. Berbeda dengan pasien dewasa, kerentanan hemodinamik mudah terjadi pada neonatus sehingga kerusakan jaringan di SSP yang bersifat hipoksik-iskemik lebih mudah terjadi. Ensefalopati sepsis merupakan salah satu manifestasi yang sering ditemukan, prevalensi antara 9\%-71\%, bergantung pada kriteria diagnostik yang digunakan. Ensefalopati sepsis adalah gangguan serebral akibat perubahan metabolik dan selular melalui mediator inflamasi. Ensefalopati sepsis dapat ditemukan pada awal perjalanan penyakit dan seringkali terjadi sebelum kegagalan organ lainnya. Lebih dari itu, ensefalopati sepsis dikaitkan dengan prognosis yang buruk. ${ }^{6,7}$
Salah satu biomarker yang sampai sekarang masih diteliti adalah NSE. Neuron-specific enolase adalah enzim glikolitik sitoplasma yang ditemukan pada sel neuron dan sel neuroendokrin. Neuronspecific enolase dilepaskan ke dalam aliran darah dan cairan serebrospinalis (CSS) selama terjadi kerusakan otak. Sepsis menyebabkan respons inflamasi berlebih sehingga terjadi kerusakan sawar darah otak, disfungsi serebrovaskular dan oksigenasi, gangguan neurotransmiter, degenerasi sel neuron, edema serebral yang berakhir pada kematian sel, baik melalui mekanisme apoptosis atau nekrosis. Kerusakan sel neuron tersebut yang menyebabkan dilepaskannya NSE ke dalam darah atau CSS. ${ }^{8}$

\section{Metode}

Penelitian analitik observasional dengan pendekatan kohort prospektif. Penelitian dilakukan di neonatal intensive care unit (NICU) RSUP Kandou Manado dari bulan Agustus 2015-November 2015. Sampel penelitian adalah seluruh populasi terjangkau sepsis neonatorum yang memenuhi kriteria inklusi dan eksklusi. Cara pengambilan sampel adalah consecutive sampling. Kriteria inklusi adalah neonatus cukup bulan tersangka sepsis (berdasarkan faktor risiko, gejala klinis dan pemeriksaan laboratorium), lahir secara per vaginam atau sectio caesaria dan orang tua/ wali ikut menyetujui untuk ikut serta dalam penelitian dan menandatangani informed consent. Kriteria eksklusi adalah neonatus dengan kelainan bawaan, gemeli, asfiksia neonatorum, hypoxic ischemic encephalopathy dan trauma kepala. Penelitian dilaksanakan atas persetujuan Komite Etik FK Unsrat. Analisis data secara komputerisasi menggunakan perangkat lunak SPSS versi 22 , nilai $\mathrm{p}<0,05$ signifikan. Analisis yang digunakan adalah analisis regresi logistik dan korelasi Pearson.

\section{Hasil}

Karakterisitik 42 bayi sepsis dalam penelitian tertera pada Tabel 1. Hubungan kadar NSE serum dengan mortalitas yang dianalisis dengan menggunakan regresi logistik menunjukkan hubungan yang bermakna antara kadar NSE serum dengan mortalitas $(\mathrm{p}=0,001)$. Semakin tinggi kadar NSE serum maka semakin besar 
Ricky Hartanto dkk: Hubungan kadar neuron-specific enolase serum dengan mortalitas pada sepsis neonatorum

Tabel 1. Karakteristik subyek penelitian

\begin{tabular}{lccc}
\hline Jenis kelamin & \multicolumn{2}{c}{ Mortalitas, $n(\%)$} & Jumlah \\
& Sembuh $(\mathrm{n}=19)$ & Meninggal $(\mathrm{n}=23)$ & \\
\hline Laki-laki & $11(58)$ & $13(57)$ & $24(57)$ \\
Perempuan & $8(42)$ & $10(43)$ & $18(43)$ \\
Rerata NSE serum $(\mu \mathrm{g} / \mathrm{L})(\mathrm{SB})$ & $13,3 \pm 7,4$ & $39,9 \pm 15,4$ & $27,9 \pm 18,2$ \\
\hline
\end{tabular}

$\mathrm{SB}=$ simpang baku

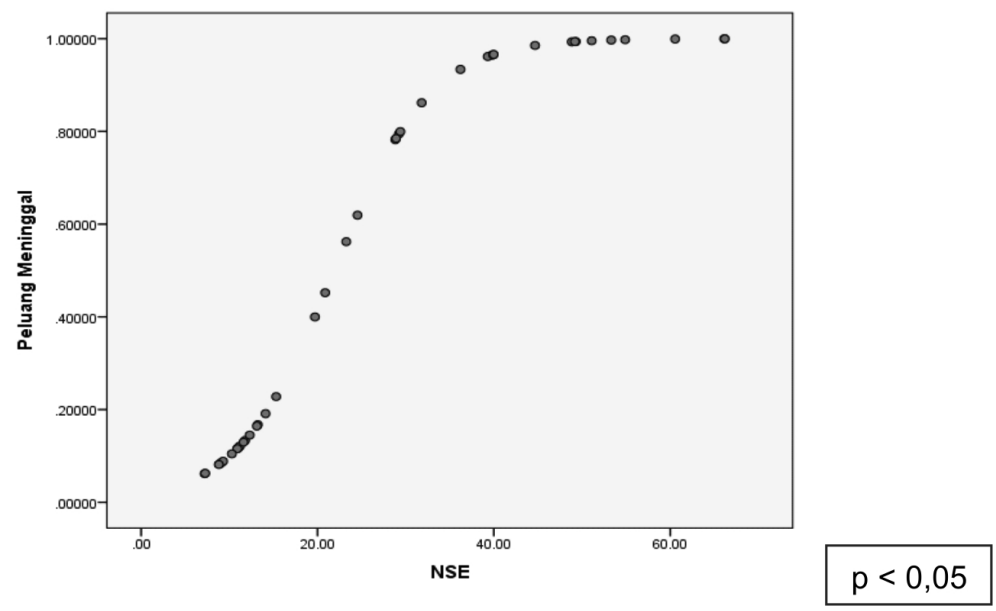

Gambar 1. Scatterplot hubungan kadar NSE serum dengan mortalitas

peluang bayi dengan sepsis yang meninggal. Besarnya korelasi kedua variabel adalah $r=0,738$ dengan $\mathrm{p}<0,001$ (Gambar 1). Berdasarkan analisis ini dapat ditentukan cut off point kadar NSE serum, yaitu 21,9 $\mu \mathrm{g} / \mathrm{L}$. Titik potong ini memberikan nilai sensitivitas $91,3 \%$ dan nilai spesifisitas $94,7 \%$.

\section{Pembahasan}

Kami mendapatkan bayi berjenis kelamin laki-laki lebih banyak menderita sepsis. Hasil penelitian kami serupa dengan penelitian sebelumnya. Penelitian tahun 2008 di Jakarta dilaporkan bayi laki-laki lebih banyak menderita sepsis daripada bayi perempuan. ${ }^{9}$ Penelitian di Denpasar juga melaporkan insiden sepsis neonatorum lebih tinggi pada bayi laki-laki dibandingkan perempuan. ${ }^{10,11}$ Lawn $\mathrm{dkk}^{12}$ melaporkan bahwa terdapat pengaruh jenis kelamin terhadap insiden sepsis neonatorum, lebih banyak dijumpai pada bayi laki-laki daripada bayi perempuan. Hal tersebut disebabkan oleh peran faktor sex-linked pada kerentanan pejamu terhadap infeksi. Gen yang terletak pada kromosom $\mathrm{x}$ memengaruhi fungsi kelenjar timus dan sintesis imunoglobulin. Secara teoritis dikatakan bahwa bayi laki-laki memiliki risiko sepsis dua kali lebih besar dari bayi perempuan. ${ }^{1,3,12}$ Mortalitas keseluruhan dari subjek penelitian kami 54,8\%, lebih tinggi dibandingkan beberapa penelitian yang telah dilakukan sebelumnya. Pada periode JanuariDesember 2008 di RSUP Sanglah, angka mortalitas sepsis neonatorum $28,3 \% .{ }^{10}$ Masih di rumah sakit yang sama, mortalitas sepsis neonatorum periode JanuariDesember 2010 30,4\%. ${ }^{11}$

Kami mendapatkan rerata kadar NSE serum pada bayi yang menderita sepsis adalah $27,91 \mu \mathrm{g} / \mathrm{L}$. Kadar NSE serum lebih tinggi bila dibandingkan dengan penelitian sebelumnya yang mendapatkan rerata kadar NSE serum $(19,2 \pm 6,4) \mu \mathrm{g} / \mathrm{L}$ pada 13 pasien sepsis berat dan syok septik yang meninggal dibandingkan dengan 16 pasien yang sembuh dari sepsis dan syok septik $(11,1 \pm 3,2) \mu \mathrm{g} / \mathrm{L}$. Hal tersebut dapat disebabkan oleh perbedaan karakteristik subjek penelitian. Subjek penelitian adalah neonatus dengan 
sepsis awitan dini atau lambat, dibandingkan dengan penelitian oleh Weigand $\mathrm{dkk}^{13}$ pada orang dewasa. Bayi memiliki respons imunologi yang berbeda dengan orang dewasa, yang mungkin juga memiliki respons terhadap sepsis yang berbeda pula. Penelitian kohort prospektif oleh Hsu dkk, ${ }^{14}$ terhadap 24 anak dengan syok septik, didapatkan peningkatan kadar NSE serum dibandingkan kontrol $((96,6 \pm 8,9$ versus $4,0 \pm 1,3)$ $\mu \mathrm{g} / \mathrm{L} ; \mathrm{p}<0,001)$. Kesimpulan penelitian tersebut adalah biomarker kerusakan neurologis meningkat pada anak dengan syok septik dan mengindikasikan adanya kerusakan neurologis yang bersifat sementara atau permanen.

Terdapat hubungan bermakna antara kadar NSE serum dengan mortalitas pada sepsis neonatorum. Semakin tinggi kadar NSE serum, semakin tinggi mortalitas yang terjadi (semakin tinggi kadar NSE serum maka semakin besar kemungkinan bayi dengan sepsis akan meninggal). Weigand $\mathrm{dkk}^{13}$ melaporkan bahwa pada sepsis ditemukan kadar NSE serum dapat berperan sebagai marker kerusakan neurologis dan prediktor luaran pasien sepsis. Dalam penelitian tersebut didapatkan bahwa kadar NSE serum lebih tinggi pada kelompok sepsis berat dan syok septik yang meninggal dibandingkan dengan yang sembuh.

Cut-off kadar NSE serum adalah 21,9 $\mu \mathrm{g} / \mathrm{L}$ memberikan nilai sensitivitas $91,3 \%$ dan nilai spesifisitas $94,7 \%$ sebagai prediktor mortalitas pada sepsis neonatorum. Hasil penelitian sebelumnya pada pasien dewasa didapatkan nilai cut-off $14 \mu \mathrm{g} / \mathrm{L}$, dapat dijadikan sebagai prediktor mortalitas pada kasus sepsis berat dan syok septik dengan nilai sensitivitas $85 \%$ dan nilai spesifisitas $95 \% .{ }^{13}$ Yao $\mathrm{dkk}^{15}$ melaporkan peningkatan kadar NSE serum pada pasien dengan ensefalopati sepsis dibandingkan dengan yang tidak menderita ensefalopati. Kadar NSE serum dengan cut-off 24,15 $\mu \mathrm{g} / \mathrm{L}$ untuk diagnosis ensefalopati sepsis memiliki sensitivitas 54,2\% dan spesifisitas $82,8 \%$.

Belum ada penelitian yang menganalisis hubungan kadar NSE serum dengan mortalitas pada sepsis neonatorum di Indonesia. Hasil penelitian kami memberikan informasi bahwa sepsis neonatorum memiliki luaran yang buruk pada perkembangan neurologis bayi di kemudian hari karena sepsis menyebabkan kerusakan, baik bersifat sementara atau permanen.

Keterbatasan dari penelitian kami adalah pemeriksaan kadar NSE serum hanya dilakukan satu kali, yaitu pada saat pasien masuk NICU. Penelitian lanjutan dapat dilakukan dengan melakukan pengukuran kadar NSE serum saat pasien masuk dan ketika mengalami perburukan atau sembuh (serial).

\section{Kesimpulan}

Didapatkan semakin tinggi kadar NSE serum maka semakin besar kemungkinan bayi dengan sepsis meninggal dalam perawatan di NICU.

\section{Daftar pustaka}

1. Aminullah A. Sepsis pada bayi baru lahir. Dalam: Kosim MS, Yunanto A, Dewi R, Sarosa GI, Usman A, penyunting. Buku Ajar Neonatologi. Edisi 1. Jakarta: Badan Penerbit IDAI; 2008.h.170-87.

2. Triphati S, Malik GK. Neonatal sepsis: past, present and future; a review article. Int J Med Upd 2010;5:45-54.

3. Stoll BJ. Infections of the neonatal infant. Dalam: Behrman RE, Kliegman RM, Jenson HB, penyunting. Nelson Textbook of Pediatrics. Edisi ke-19. Philadelphia: WB Saunders; 2011.h.623-40.

4. Silviera RC, Giacomini C, Procianoy RS. Neonatal sepsis and septic shock: concepts update and review. Rev Bras Ter Intensiva 2010;22:280-90.

5. Wynn JL, Wong HR. Pathophysiology and treatment of septic shock in neonates. Clin Perinatol 2010;37:439-79.

6. Chaundry N, Duggal AK. Sepsis associated encephalopathy. Adv Med 2014;20:1-16.

7. Ziaja M. Septic encephalopathy. Curr Neurol Neurosci Rep 2013;13:383-9.

8. Zenaide PV, Flores DG. Biomarkers in septic encephalopathy: a systemic review of clinical studies. Rev Bras Ter Intensiva 2013;25:56-62.

9. Juniatiningsih A, Aminullah A, Firmansyah A. Profil mikroorganisme penyebab sepsis neonatorum di departemen ilmu kesehatan anak rumah sakit Cipto Mangunkusumo Jakarta. Sari Pediatri 2008;10:60-5.

10. Kardana IM. Incidence and factors associated with mortality of neonatal sepsis. Paediatr Indones 2011;51:144-8.

11. Putra PJ. Insiden dan faktor-faktor yang berhubungan dengan sepsis neonatus di RSUP Sanglah Denpasar. Sari Pediatri 2012;14:205-10.

12. Lawn JW, Katende KW, Cousens SN. Estimating the causes 4 million neonatal deaths in the year 2000. Int J Epid 2006;35:706-18. 
13. Wiegand MA, Volkmann M, Schmidt H, Martin E, Bohrer H, Bardenheuer HJ. Neuron specific enolase as a marker of fatal outcome in patients with severe sepsis or septic shock. Anesthesiology 2000;92:905-7.

14. Hsu AA, Fenton K, Weinsten S, Carpenter J, Dalton H, Bell MJ. Neurological injury markers in children with septic shock. Pediatr Crit Care Med 2008;9:245-51.

15. Yao B, Zhang LN, Ai YH, Liu ZY, Huang L. Serum $\mathrm{S} 100 \mathrm{~B}$ is a better biomarker than neuron specific enolase for sepsis associated encephalopathy and determining its prognosis: a prospective and observational study. Neurochem Res 2014;39:1263-9. 